\title{
Current Treatment Options for Human Epidermal Growth Factor Receptor 2-Directed Therapy in Metastatic Breast Cancer: An Indian Perspective
}

\begin{abstract}
Human epidermal growth factor receptor 2 (HER2)-positive is an aggressive subtype of breast cancer and has historically been associated with poor outcomes. The availability of various anti-HER2 therapies, including trastuzumab, lapatinib, pertuzumab, and trastuzumab emtansine (TDM-1), has remarkably improved the clinical outcomes in patients with HER2-positive metastatic breast cancer $(\mathrm{mBC})$. However, there is a need to optimize treatment within this population, given the wide variability in clinical presentation. Additionally, geographical and socio-economic considerations too need to be taken into account. To clarify and collate evidence pertaining to HER2-positive metastatic breast cancer, a panel of medical and clinical oncologists from across India developed representative clinical scenarios commonly encountered in clinical practice in the country. This was followed by two meetings wherein each clinical scenario was discussed in detail and relevant evidence appraised. The result of this process is presented in this manuscript as evidence followed by therapeutic recommendations of this panel for management of HER2-positive $\mathrm{mBC}$ in the Indian population.
\end{abstract}

Keywords: Human epidermal growth factor receptor 2 positive, India, metastatic breast cancer, targeted therapy

\section{Introduction}

An estimated $15 \%-20 \%$ of women with breast cancer overexpress human epidermal growth factor receptor 2 (HER2). ${ }^{[1,2]}$ Ghosh et al. reported that $16.7 \%$ and $8.1 \%$ of patients $(n=2001)$ with breast cancer presenting at their referral cancer center in Mumbai had HER2 immunochemistry (IHC) scores of $3+$ and $2+$, respectively, ${ }^{[3]}$ while Doval et al. found that $23 \%$ of a cohort of 1284 breast cancer patients from their institution in New Delhi were HER2 positive. ${ }^{[4]}$ More recently, Chatterjee et al. ${ }^{[5]}$ and Agrawal et al. ${ }^{[6]}$ have reported HER2-positive rates in locally advanced breast cancers to be as high as $38 \%$ $40 \%$ based on the use of quality-assured automated IHC and fluorescence in situ hybridization tests.

HER2-positive subtype of breast cancer has historically been associated with poor clinical outcomes. ${ }^{[7]}$ The disease

This is an open access journal, and articles are distributed under the terms of the Creative Commons Attribution-Non Commercial-ShareAlike 4.0 License, which allows others to remix, tweak, and build upon the work non-commercially, as long as appropriate credit is given and the new creations are licensed under the identical terms.

For reprints contact: reprints@medknow.com course is typically aggressive with a high propensity for early metastases, relapse, and shorter survival than other subtypes. In this backdrop, the use of several HER2-directed therapies [Table 1] has substantially improved the outcomes in this population..$^{[8-11]}$ These anti-HER2 therapies are available in India.

However, in certain clinical scenarios, the treatment decision-making becomes arduous due to limited availability of evidence. Moreover, the interpretation and applicability of Western data in Indian population could be challenging given the diverse socio-cultural-economic environment. This article discusses some representative scenarios commonly seen in India, examines the available high-level evidence relevant to such scenarios, and provides treatment recommendations based on the consensus of a panel of experts. However, the panel acknowledges that for any given patient, the clinical judgment of the treating physician,

How to cite this article: Sudeep G, Sanjoy C, Jagdish N, Shyam A, Manish S, Alurkar SS, et al. Current treatment options for human epidermal growth factor receptor 2-directed therapy in metastatic breast cancer: An Indian perspective. Indian J Med Paediatr Oncol 2018;39:368-79.

\section{Gupta Sudeep, Chatterjee Sanjoy ${ }^{1}$, Nigade Jagdish', Aggarwal Shyam ${ }^{3}$, Singhal Manish ${ }^{4}$, Alurkar SS $^{5}$, Kukreja Anil'2, Smruti BK ${ }^{6}$, Nag Shona ${ }^{7}$, Agarwal Amit ${ }^{8}$, Agarwal Vijay ${ }^{9}$, Chacko RT ${ }^{10}$, Desai Chirag ${ }^{11}$, Goswami Chanchal ${ }^{12}$, Keechilat Pavithran ${ }^{13}$, Patil Poonam ${ }^{14}$, Prasad Krishna ${ }^{15}$, Rajendranath Rejiv $^{16}$, Rao $\mathbf{R R}^{17}$, Sahoo TP ${ }^{18}$, Singh Ashish ${ }^{10}$, Singh Randeep ${ }^{19}$, Srinivasan Sankar ${ }^{16}$, Warrier Arun ${ }^{20}$, Swarup Binay ${ }^{21}$, Bhattacharya Priyanka ${ }^{21}$, Advani $\mathbf{S H}^{22}$}

Department of Medical Oncology, Tata Memorial Centre, ACTREC, Navi Mumbai, Maharashtra, 'Department of Radiation Oncology, Tata Medical Center, Kolkata, West Bengal, ${ }^{2}$ Medical, Roche

Access this article online Website: www.ijmpo.org DOI: 10.4103/ijmpo.ijmpo_201_17 Quick Response Code:

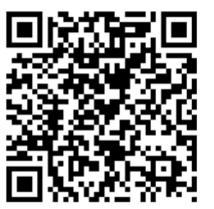


Products (India) Pvt. Ltd., Mumbai, Maharashtra, ${ }^{3}$ Department of Medical Oncology, Sir Ganga Ram Hospital, ${ }^{4}$ Department of Medical Oncology, Indraprastha Apollo Hospitals, New Delhi, ${ }^{5}$ Department of Oncology, Apollo Hospitals, Ahmedabad, Gujarat, ${ }^{6}$ Department of Medical Oncology, Bombay Hospital, Mumbai, ${ }^{7}$ Department of Oncology, Jehangir Hospital, Pune, Maharashtra, ${ }^{8}$ Department of Medical Oncology, BL Kapoor Hospital, Delhi, ${ }^{9}$ Department of Medical Oncology, Healthcare Global, Bengaluru, Karnataka, ${ }^{10}$ Department of Medical Oncology, Christian Medical College, Vellore, Tamil Nadu, ${ }^{11}$ Hemato-Oncology Clinic, Vedanta Super Speciality Hospital, Ahmedabad, ${ }^{12}$ Department of Oncology, Medica Superspecialty Hospital, Kolkata, West Bengal, ${ }^{13}$ Department of Medical Oncology, Amrita Institute of Medical Sciences, Kochi, Kerala, ${ }^{14}$ Department of Medical Oncology, Manipal Hospital, Bengaluru, ${ }^{15}$ Department of Medical Oncology, Kasturba Medical College, Mangalore, Karnataka, ${ }^{16}$ Department of Medical Oncology, Apollo Speciality Hospital, Chennai, Tamil Nadu, ${ }^{17}$ Department of Medical Oncology, Max Super Speciality Hospital, Delhi, ${ }^{18}$ Department of Medicine, Chirayu Medical College, Bhopal, Madhya Pradesh, ${ }^{19}$ Department of Oncology, Artemis Hospital, Gurgaon, Haryana, ${ }^{20}$ Department of Medical Oncology, Aster Medicity Hospital, Kochi, Kerala, ${ }^{21}$ Medical Roche Products (India), ${ }^{22}$ Medical Oncology, Mumbai, Maharashtra, India

Address for correspondence:

Dr. Sudeep Gupta,

Room No. 305, $3^{\text {rd }}$ Floor, Paymaster Shodhika, Advanced Centre for Treatment, Research and Education in Cancer, Mumbai - 410210 ,

Maharashtra, India.

E-mail: sudeepgupta04@yahoo.com

\begin{tabular}{|c|c|c|}
\hline $\begin{array}{l}\text { Anti-HER2 } \\
\text { agent }\end{array}$ & Indication & $\begin{array}{l}\text { Year of approval } \\
\text { by the US FDA }\end{array}$ \\
\hline Trastuzumab & $\begin{array}{l}\text { Trastuzumab }\left(\text { Herceptin }^{\mathrm{TM}}\right) \\
\text { combined with paclitaxel in } \\
\text { patients with mBC whose } \\
\text { tumors overexpress HER2 } \\
\text { protein and who have not } \\
\text { received chemotherapy for } \\
\text { their metastatic disease }\end{array}$ & 1998 \\
\hline Lapatinib & $\begin{array}{l}\text { Lapatinib }\left(\text { Tykerb }{ }^{\circledR}\right) \text { for } \\
\text { use in combination with } \\
\text { capecitabine for treatment } \\
\text { of patients with advanced } \\
\text { breast cancer or mBC } \\
\text { whose tumors overexpress } \\
\text { HER2 (ErbB2), and who } \\
\text { have received prior therapy } \\
\text { including anthracycline, } \\
\text { taxane, and trastuzumab }\end{array}$ & 2007 \\
\hline Pertuzumab & $\begin{array}{l}\text { Pertuzumab }\left(\text { Perjeta }^{\mathrm{TM}}\right) \\
\text { for use in combination } \\
\text { with trastuzumab and } \\
\text { docetaxel for the treatment } \\
\text { of HER2-positive mBC } \\
\text { who have not received } \\
\text { prior anti-HER2 therapy or } \\
\text { chemotherapy for metastatic } \\
\text { disease }\end{array}$ & 2012 \\
\hline T-DM1 & $\begin{array}{l}\text { Trastuzumab } \\
\text { emtansine }\left(K^{2} \text { dcyla }^{\mathrm{TM}}\right) \text { for } \\
\text { use as a single agent for the } \\
\text { treatment of patients with } \\
\text { HER2-positive } \mathrm{mBC} \text {, who } \\
\text { had previously received } \\
\text { treatment with trastuzumab } \\
\text { and taxane, either separately } \\
\text { or in combination }\end{array}$ & 2013 \\
\hline
\end{tabular}

FDA - Food and Drug Administration; HER2 - Human epidermal growth factor receptor 2; $\mathrm{mBC}$ - Metastatic breast cancer; T-DM1 - Trastuzumab emtansine

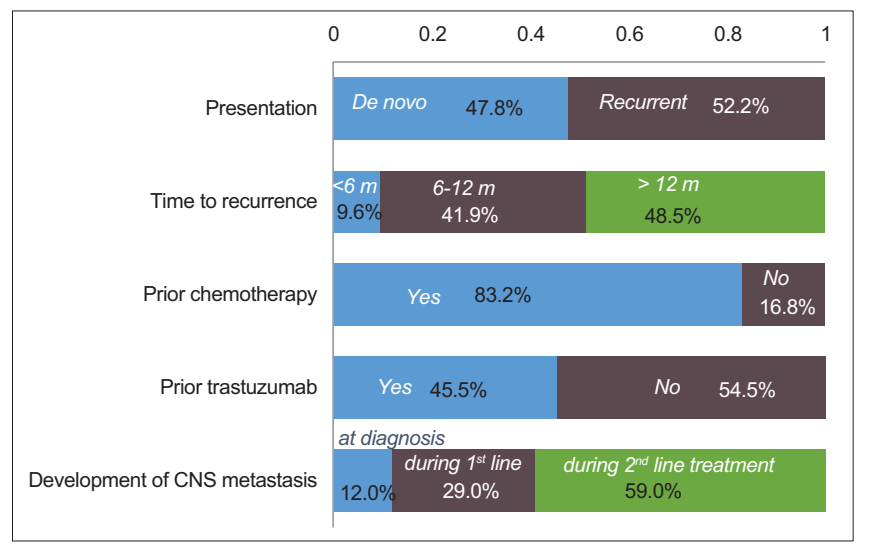

Figure 1: Profile of patients with human epidermal growth factor receptor 2-positive metastatic breast cancer, based on a survey of expert panel of nine medical oncologists across India. (Note: The graph represents responses received from the experts, and the total may not exactly equal $100 \%$ ). HER2 - Human epidermal growth factor receptor 2

considering all factors, should take precedence over expert recommendations.

\section{Methods}

Based on a survey [Figure 1], a panel of nine medical and clinical oncologists with expertise in the treatment of breast cancer developed representative clinical scenarios commonly seen in practice in India. This was followed by two face-to-face meetings, the first at New Delhi on April 08, 2016 (attended by ten medical and clinical oncologists, including the nine who developed the scenarios) and the second at Mumbai on January 22, 2017 (attended by 14 medical and clinical oncologists).

The panel discussed the choice of treatment for each clinical scenario based on the available evidence from relevant Phase 3 randomized controlled trials. The final treatment recommendation was reached by consensus or vote. Panelists were asked to indicate their choices on the assumption that the patients had access to all approved anti-HER2 drugs and were able to afford treatment or were adequately covered by insurance. 
Clinical Scenario 1: First-Line Treatment for Human Epidermal Growth Factor Receptor 2-Positive Metastatic Breast Cancer

A 56-year-old woman with HER2-positive, hormone receptor-negative breast cancer underwent surgery for a 25-mm, Grade 3 invasive duct cancer. Postoperatively, she was started on doxorubicin and cyclophosphamide, followed by paclitaxel and trastuzumab (AC $\rightarrow \mathrm{TH}$ regimen), followed by continuation of adjuvant trastuzumab, for a total anti-HER2 therapy duration of 1 year. Two years after completion of adjuvant trastuzumab therapy, she developed biopsy-confirmed HER2-positive, hormone receptor-negative metastatic disease in the liver.

In addition, two subscenarios in the first-line metastatic breast cancer $(\mathrm{mBC})$ setting were also considered. In the first subscenario, the same representative patient as above had received a similar treatment with the exception that she did not receive adjuvant trastuzumab (i.e., she was trastuzumab naïve at the time of developing metastases). In the second subscenario, the same patient as above presents with de novo HER2-positive $\mathrm{mBC}$ at the time of initial diagnosis.

The following therapeutic options were discussed for this scenario and subscenarios:

1. Combination of trastuzumab and taxane

2. Combination of lapatinib and taxane

3. Combination of pertuzumab, trastuzumab, and docetaxel

4. Combination of trastuzumab, paclitaxel, and everolimus

5. Trastuzumab emtansine (T-DM1).

\section{Literature analysis}

The Herceptin trial (H0648 g) conducted by Slamon et al. ${ }^{[8]}$ was the first large Phase 3 trial to demonstrate that targeting a specific dysfunctional genetic alteration in a human solid tumor was feasible and could lead to clinical benefits. This pivotal study included 450 women with HER2-positive $\mathrm{mBC}$ who had not previously received chemotherapy for metastatic disease, but could have received anthracycline in the (neo) adjuvant setting (were treated with trastuzumab and paclitaxel). ${ }^{[12]}$ Clinical outcomes in the trastuzumab plus chemotherapy arm were significantly superior to those in the chemotherapy-alone arm [Table 2], although concurrent anthracycline and trastuzumab had increased the risk of cardiac dysfunction and led to the approval of Herceptin with paclitaxel in HER2-positive $\mathrm{mBC}$ by the US-Food and Drug Administration. The MA 31 trial was an interesting comparison between different approaches to HER2 blockade in $\mathrm{mBC}$ - oral small molecule versus intravenous antibody. It compared the efficacy of lapatinib versus trastuzumab in combination with taxanes as first-line treatment for HER2-positive mBC. After 24 weeks of chemotherapy plus HER2-directed therapy, the respective anti-HER2 monotherapy was continued until disease progression. In both arms, $18 \%$ patients had received prior (neo) adjuvant trastuzumab therapy and $42 \%$ of patients had de novo $\mathrm{mBC}$ at primary diagnosis. The results showed that patients in the trastuzumab arm had longer progression-free survival (PFS) than those in the lapatinib arm [Table 2]; however, there was no significant difference in overall survival (OS) between the two arms. ${ }^{[13]}$ Patients treated with lapatinib displayed characteristic adverse effects, especially gastrointestinal and skin toxicity.

The CLEOPATRA trial investigated single-versus-dual HER2 blockade (trastuzumab plus placebo versus trastuzumab plus pertuzumab, a HER2 dimerization inhibitor), in combination with a taxane, in HER2-positive $\mathrm{mBC} \cdot{ }^{[10,14]}$ In this trial, approximately $50 \%$ of patients were treatment naïve and only $10 \%$ of patients had received trastuzumab in the (neo) adjuvant setting, as recruitment began $<2$ years after the initial approval of adjuvant trastuzumab. ${ }^{[19]}$ Median PFS in the pertuzumab arm was significantly longer than that in the comparator arm [Table 2]; the between-group difference was statistically significant across all subgroups. In the subgroup of patients who had received adjuvant or neoadjuvant therapy with trastuzumab, the median PFS was increased by 6.5 months in the pertuzumab arm (hazard ratio [HR], $0.62 ; 95 \%$ confidence interval, $0.35-1.07){ }^{[15]}$ Despite the presence of visceral metastasis in $78 \%$ of the patients, the median survival approached 5 years in the pertuzumab arm. Indeed, at the time of reporting, patients had spent more time off pertuzumab than on it (18 months of PFS followed by approximately 38 months of post-PFS). ${ }^{[14]}$ Similar to the "carryover" effect observed after cessation of tamoxifen, ${ }^{[20]}$ the survival curves continued to diverge; this phenomenon is usually not seen with other oncology drugs. Post the trial treatment, nearly $72 \%$ of the patients received additional HER2-directed treatment and this proportion was comparable in both the study arms. There was a 10-month difference in the post-PFS between the pertuzumab and the control arm, ${ }^{[14]}$ although the OS was comparable in patients with and without prior trastuzumab exposure. ${ }^{[15]}$ The adverse events reported in the study included neutropenia, which was primarily attributed to concomitant treatment with docetaxel. ${ }^{[21]}$ It may be noted that in the safety analysis of the ongoing PERUSE study $(n=1436)$, the preliminary toxicity profile of first-line pertuzumab, trastuzumab, and the investigator's choice of taxane regimen was generally consistent with the previous clinical experience of pertuzumab and the known taxane safety profile. ${ }^{[22]}$

A real-world, retrospective noninterventional study ${ }^{[23]}$ assessed the clinical outcomes of patients treated with pertuzumab containing therapy as first-line treatment in US community oncology practices. Most patients (93.6\%) were treated with a combination of pertuzumab, trastuzumab, and a taxane (docetaxel or paclitaxel or nab-paclitaxel). In line with the current practice, $61.5 \%$ of patients received (neo) adjuvant trastuzumab. The median PFS (16.9 months) and toxicity profile were similar to that observed in the CLEOPATRA trial. 


\begin{tabular}{|c|c|c|c|}
\hline Trial & Treatment arms & Treatment-specific criteria & Results \\
\hline $\mathrm{H}_{0648 \mathrm{~g}^{[8]}}$ & $\begin{array}{l}\text { Chemotherapy* }+ \\
\text { trastuzumab }(n=235) \text { versus } \\
\text { chemotherapy }(n=234)\end{array}$ & $\begin{array}{l}\text { HER2-positive } \mathrm{mBC} \text {; no previous } \\
\text { chemotherapy for metastatic disease }\end{array}$ & $\begin{array}{l}\text { Trastuzumab + chemotherapy } \\
\text { versus chemotherapy } \\
\text { Median TTP: } 7.4 \text { months versus } \\
4.6 \text { months (RR: } 0.51 \text {; } \\
P<0.001) \\
\text { Median OS: } 25.1 \text { months } \\
\text { versus } 20.3 \text { months } \\
\text { (RR: } 0.80 ; P=0.046) \\
\text { Trastuzumab }+ \text { paclitaxel }(n=92) \\
\text { versus paclitaxel }(n=96) \\
\text { Median TTP: } 6.9 \text { months versus } \\
\text { 3.0 months (RR: } 0.38 ; \\
P<0.001) \\
\text { Median OS } 22.1 \text { months versus } \\
18.4 \text { months (RR: } 0.80 ; P=0.17 \text { ) }\end{array}$ \\
\hline MA.31 $1^{[13]}$ & $\begin{array}{l}\text { Lapatinib }+ \text { taxane }(n=326) \\
\text { versus trastuzumab }+ \text { taxane } \\
(n=326)\end{array}$ & $\begin{array}{l}\text { HER2-positive } \mathrm{mBC} \text {; prior (neo) } \\
\text { adjuvant trastuzumab and/or taxane } \\
\text { therapy allowed provided last dose } \\
\geq 1 \text { year before randomization }(18 \% \\
\text { patients) }\end{array}$ & $\begin{array}{l}\text { Lapatinib + taxane versus } \\
\text { trastuzumab + taxane } \\
\text { Median PFS: } 9 \text { months } \\
\text { versus } 11.3 \text { months } \\
\text { (HR: } 1.37 ; P=0.001) \\
\text { Median OS: Median not } \\
\text { observed (HR: } 1.28 ; P=0.11)\end{array}$ \\
\hline CLEOPATRA $^{[10,14,15]}$ & $\begin{array}{l}\text { Trastuzumab }+ \text { docetaxel }+ \\
\text { pertuzumab }(n=402) \text { versus } \\
\text { trastuzumab }+ \text { docetaxel }+ \\
\text { placebo }(n=406)\end{array}$ & $\begin{array}{l}\text { Locally recurrent, unresectable, or } \\
\text { metastatic HER2+ve BC; Prior (neo) } \\
\text { adjuvant chemotherapy including } \\
\text { trastuzumab and/or taxane allowed if } \\
\geq 1 \text { year has elapsed between treatment } \\
\text { completion and detection of mBC }\end{array}$ & $\begin{array}{l}\text { Trastuzumab }+ \text { docetaxel }+ \\
\text { pertuzumab versus trastuzumab }+ \\
\text { docetaxel }+ \text { placebo } \\
\text { Overall population } \\
\text { Median PFS: } 18.5 \text { months } \\
\text { versus } 12.4 \text { months } \\
\text { (HR: } 0.62 ; P<0.001 \text { ) } \\
\text { Median OS: } 56.5 \text { months } \\
\text { versus } 40.8 \text { months } \\
\text { (HR: } 0.68 ; P<0.001 \text { ) } \\
\text { Prior (neo) adjuvant } \\
\text { trastuzumab-treated patients } \\
\text { (12\%, } n=88 \text { ) } \\
\text { Median PFS: } 16.9 \text { months } \\
\text { versus } 10.4 \text { months } \\
\text { (HR: } 0.62 \text { ) } \\
\text { Median OS: } 53.8 \text { months } \\
\text { versus } 46.2 \text { months } \\
\text { (HR: } 0.68 \text { ) }\end{array}$ \\
\hline BOLERO-1[16] & $\begin{array}{l}\text { Trastuzumab }+ \text { paclitaxel }+ \\
\text { everolimus }(n=480) \text { versus } \\
\text { trastuzumab }+ \text { paclitaxel }+ \\
\text { placebo }(n=239)\end{array}$ & $\begin{array}{l}\text { Locally recurrent, unresectable, or } \\
\text { metastatic HER2+ve BC; } \\
\text { no prior anthracycline/taxane in } \\
\text { the metastatic setting; previous } \\
\text { (neo) adjuvant trastuzumab and } \\
\text { chemotherapy allowed, } \\
\text { if } \geq 12 \text { months elapsed at } \\
\text { the date of } \\
\text { randomization ( } 11 \% \text { patients) }\end{array}$ & $\begin{array}{l}\text { Trastuzumab }+ \text { everolimus versus } \\
\text { trastuzumab }+ \text { placebo } \\
\text { Median PFS: } 14.95 \text { months } \\
\text { versus: } 14.49 \text { months } \\
\text { (HR: } 0.89 ; P=0.1166)\end{array}$ \\
\hline
\end{tabular}


Table 2: Contd...

\begin{tabular}{|c|c|c|c|}
\hline Trial & Treatment arms & Treatment-specific criteria & Results \\
\hline \multirow[t]{9}{*}{ MARIANNE $^{[17]}$} & \multirow{9}{*}{$\begin{array}{l}\text { T-DM1 }(n=367) \text { versus T-DM1 } \\
+ \text { pertuzumab }(n=363) \text { versus } \\
\text { trastuzumab }+ \text { taxane }(n=365)\end{array}$} & \multirow{9}{*}{$\begin{array}{l}\text { Unresectable, progressive, or recurrent } \\
\text { locally advanced, or previously } \\
\text { untreated } \mathrm{MBC} \text {; prior (neo) adjuvant } \\
\text { chemotherapy with vinca alkaloid or } \\
\text { taxane allowed if }>6 \text { months since } \\
\text { diagnosis of advanced BC }\end{array}$} & $\begin{array}{l}\text { T-DM1 versus trastuzumab }+ \\
\text { taxane }\end{array}$ \\
\hline & & & Overall patient population \\
\hline & & & $\begin{array}{l}\text { Median PFS: } 14.1 \text { months } \\
\text { versus } 13.7 \text { months (HR: } 0.91 \text {; } \\
P=0.31 \text { ) }\end{array}$ \\
\hline & & & $\begin{array}{l}\text { Prior (neo) adjuvant } \\
\text { trastuzumab-/lapatinib-treated } \\
\text { patients }(31 \%, n=226)\end{array}$ \\
\hline & & & $\begin{array}{l}\text { Median PFS: } 15.2 \text { months } \\
\text { versus } 10.3 \text { months (HR: } 0.75)\end{array}$ \\
\hline & & & $\begin{array}{l}\text { T-DM1 + pertuzumab versus } \\
\text { trastuzumab + taxane }\end{array}$ \\
\hline & & & Overall population \\
\hline & & & $\begin{array}{l}\text { Median PFS: } 15.2 \text { months } \\
\text { versus } 13.7 \text { months } \\
\text { (HR: } 0.87 ; P=0.14 \text { ) }\end{array}$ \\
\hline & & & $\begin{array}{l}\text { Median OS was not reached in } \\
\text { any treatment group }\end{array}$ \\
\hline \multirow[t]{7}{*}{ EMILIA $^{[11,18]}$} & \multirow[t]{7}{*}{$\begin{array}{l}\text { T-DM1 }(n=495) \text { versus lapatinib } \\
+ \text { capecitabine }(n=496)\end{array}$} & \multirow{7}{*}{$\begin{array}{l}\text { Unresectable locally advanced or } \\
\text { metastatic HER } 2+\text { ve BC: Prior taxane } \\
\text { and trastuzumab; progression during } \\
\text { treatment for metastasis, or progression } \\
\text { within } 6 \text { months of adjuvant } \\
\text { treatment (early relapse) }\end{array}$} & $\begin{array}{l}\text { T-DM1versus lapatinib plus } \\
\text { capecitabine }\end{array}$ \\
\hline & & & Overall population \\
\hline & & & $\begin{array}{l}\text { Median PFS: } 9.6 \text { months } \\
\text { versus } 6.4 \text { months } \\
\text { (HR: } 0.65 ; P<0.001)\end{array}$ \\
\hline & & & $\begin{array}{l}\text { Median OS: } 30.9 \text { months } \\
\text { versus } 25.1 \text { months } \\
\text { (HR: } 0.68 ; P<0.001 \text { ) }\end{array}$ \\
\hline & & & $\begin{array}{l}\text { Patients with early relapse } \\
(16 \%, n=118)\end{array}$ \\
\hline & & & $\begin{array}{l}\text { Median PFS: } 10.8 \text { months } \\
\text { versus } 5.7 \text { months (HR: } 0.51)\end{array}$ \\
\hline & & & $\begin{array}{l}\text { OS: Median not reached versus } \\
27.9 \text { months (HR: } 0.61 \text { ) }\end{array}$ \\
\hline
\end{tabular}

*Chemotherapy consisted of an anthracycline plus cyclophosphamide for patients who had never before received anthracycline or paclitaxel for patients who had received adjuvant (postoperative) anthracycline. HER2+- Human epidermal growth factor receptor 2 positive; LABC - Locally advanced breast cancer; MBC - Metastatic breast cancer; OS - Overall survival; PFS - Progression-free survival; TTP - Time to progression; T-DM1 - Trastuzumab emtansine; RR - Relative risk; HR - Hazard ratio; NA - Not available; $\mathrm{BC}$ - Breast Cancer

Blockade of the HER2 receptor may trigger signaling via alternate pathways. ${ }^{[24]}$ Thus, it may be hypothesized that dual blockade (of the HER2 receptor and of a component of the downstream PI3K/AKT/mammalian target of rapamycin [mTOR] canonical pathway) could potentially lead to more effective outcomes than those achieved with HER2 targeting alone. However, in the BOLERO-1 trial that tested dual blockade of HER2 and mTOR in early $\mathrm{mBC}$, there was no significant difference in PFS between the trastuzumab plus everolimus and the trastuzumab plus placebo arms in the overall population [Table 2], although there was a potential signal of benefit in patients with hormone receptor-negative disease. ${ }^{[16]}$
The noninferiority MARIANNE trial compared T-DM1 with or without pertuzumab against trastuzumab and docetaxel. A more resistant population was also enrolled in this trial ( $>6$ months of prior [neo] adjuvant vinca alkaloid or taxane chemotherapy). Thirty percent of the patients in both arms had received prior (neo) adjuvant HER2-targeted (trastuzumab/lapatinib) therapy. No significant between-group difference in outcomes was observed in this trial [Table 2]. ${ }^{[17]}$ Of note, the combination of trastuzumab, pertuzumab, and taxane was not approved at the time of this trial and was, therefore, not tested.

A prospective observational study (registHER) by Yardley et $a l .{ }^{[25]}$ revealed significantly better outcomes in patients 
with de novo HER2-positive $\mathrm{mBC}$ as compared to those with recurrent HER2-positive mBC (OS: 41.7 vs. 32.8 months, respectively; HR: 0.766). Prior adjuvant chemotherapy perhaps renders the $\mathrm{mBC}$ more refractory to treatment because of the selection of resistant or aggressive clones of HER2-positive cells.

In the EMILIA study, a Phase 3 trial, patients treated with the antibody drug conjugate T-DM1 had significantly longer PFS and OS than those treated with a combination of lapatinib and capecitabine ${ }^{[11]}$ [Table 2]. T-DM1 significantly improved PFS and OS among patients with HER2-positive $\mathrm{mBC}$ with a disease-free interval of $<6$ months after completion of trastuzumab-based therapy in the adjuvant or neoadjuvant setting. ${ }^{[18]}$

Economic impact of various human epidermal growth factor receptor 2-directed treatments

In this context, some Indian centers have reported that there is limited access to HER2-targeted therapies for their patients, ${ }^{[3,6]}$ although this situation is now improving (Sudeep Gupta, personal communication). Anti-HER2 therapy has substantial cost implications, especially for low- and middle-income countries. ${ }^{[26]}$ Durkee et al. assessed the cost-effectiveness of pertuzumab therapy in HER2-positive $\mathrm{mBC}$ based on modeling the survival from the raw data of the CLEOPATRA study and also took into account other associated costs (cost of other drugs, hospitalization, toxicity, and subsequent treatments). They concluded that the addition of pertuzumab to trastuzumab and taxane was unlikely to be cost-effective in the United States. ${ }^{[27]}$

In India, the cost of pertuzumab is currently capped under a patient assistance program. A patient pays for 13 vials over 36 weeks (9 months), and drugs for subsequent treatment cycles are supplied free until the progression of disease. Therefore, the incremental cost-effectiveness ratio may be more favorable in the Indian context under this assistance program.

\section{Panel recommendation}

Pertuzumab in combination with trastuzumab and taxane is recommended as the first-line therapy for HER2-positive patients, including patients with or without prior (neo) adjuvant trastuzumab (relapsed $>12$ months after [neo] adjuvant use), as well as those with de novo $\mathrm{mBC}$.

For patients who have relapsed within 6 months of adjuvant trastuzumab, T-DM1 can be considered as a preferred therapeutic option. The panel acknowledges that there is insufficient level-one data to make recommendations for the group that relapse between 6 and 12 months from the end of adjuvant therapy. The use of pertuzumab-trastuzumab-taxane, T-DM1, or other anti-HER2 combinations can be considered by treating physicians in this scenario.
Clinical Scenario 2: Second-Line Treatment for Human Epidermal Growth Factor Receptor 2-Positive Metastatic Breast Cancer, Progressed on Trastuzumab

A 45-year-old woman was diagnosed 6 years ago with HER2-positive and hormone receptor negative breast cancer (T2N1M0; $20 \mathrm{~mm}$ in size, Grade 2). Following a mastectomy and axillary dissection, she underwent adjuvant treatment with doxorubicin and cyclophosphamide (AC; 4 cycles), weekly paclitaxel (12 cycles), and trastuzumab for a total duration of 1 year. She developed HER2-positive, hormone receptor-negative hepatic metastases 5 years later and was treated with weekly paclitaxel in combination with trastuzumab. After 6 months of trastuzumab monotherapy, a new lesion was found in the liver.

The following treatment regimens were considered for discussion in this scenario:

1. Lapatinib in combination with capecitabine

2. T-DM1

3. Vinorelbine in combination with trastuzumab and everolimus

4. Vinorelbine in combination with afatinib.

\section{Literature analysis}

The EGF100151 study included patients with HER2-positive $\mathrm{mBC}$ who progressed after treatment with regimens containing anthracyclines, taxanes, and trastuzumab. A significant improvement in median TTP and overall response rate was observed with lapatinib combined with capecitabine versus. monotherapy; ${ }^{[28]}$ however, there was no significant difference in median $\mathrm{OS}^{[29]}$ between the two treatment arms.

In the EMILIA trial, patients with HER2-positive $\mathrm{mBC}$ previously treated with trastuzumab in combination with a taxane were randomized to either lapatinib plus capecitabine or T-DM1. PFS and OS in the T-DM1 arm were superior than that in the lapatinib plus capacitabine arm [Table 3$].{ }^{[11]}$ In a subgroup of patients $(n=118)$ who had relapsed within 6 months of completion of adjuvant treatment, PFS with T-DM1 (10.8 months) was significantly longer than that with the combination of lapatinib and capecitabine (5.7 months). ${ }^{[18]}$ The commonly reported adverse effects of T-DM1 were elevation of liver enzymes and thrombocytopenia and both these adverse effects were manageable. ${ }^{[1]}$

The BOLERO 3 study was conducted to assess whether the addition of the mTOR inhibitor everolimus to trastuzumab would restore sensitivity to trastuzumab. In patients with HER2-positive, trastuzumab-resistant advanced breast carcinoma, there was a significant improvement in the median PFS in favor of everolimus versus the placebo group [Table 3]; however, $42 \%$ of patients in the everolimus arm experienced a serious adverse event. ${ }^{[30]}$ 
Table 3: Overview of trials in patients with human epidermal growth factor receptor 2-positive metastatic breast cancer who progressed on trastuzumab therapy

\begin{tabular}{|c|c|c|c|}
\hline Trials & Treatment arms & Treatment-specific criteria & Results \\
\hline$\overline{E G F 100151^{[9,28,29]}}$ & $\begin{array}{l}\text { Capecitabine + lapatinib }(n=198) \\
\text { versus capecitabine }(n=201)\end{array}$ & $\begin{array}{l}\text { HER2-positive } \mathrm{LABC} \text { or } \mathrm{mBC} \text { that } \\
\text { progressed after prior treatment with } \\
\text { anthracycline, taxane, and trastuzumab }\end{array}$ & $\begin{array}{l}\text { Capecitabine + lapatinib versus } \\
\text { capecitabine } \\
\text { Median TTP: } 6.2 \text { months versus } \\
4.3 \text { months (HR: } 0.57 ; P=<0.001 \text { ) } \\
\text { Median OS: } 75 \text { weeks versus } \\
64.7 \text { weeks (HR: } 0.87 ; P=0.210 \text { ) }\end{array}$ \\
\hline EMILIA $^{[11]}$ & $\begin{array}{l}\text { T-DM1 }(n=495) \text { versus lapatinib } \\
+ \text { capecitabine }(n=496)\end{array}$ & $\begin{array}{l}\text { Unresectable locally advanced or } \\
\text { metastatic HER2+ve BC: Prior taxane } \\
\text { and trastuzumab; progression during } \\
\text { treatment for metastasis, or progression } \\
\text { within } 6 \text { months of adjuvant treatment }\end{array}$ & $\begin{array}{l}\text { T-DM1 versus lapatinib }+ \text { capecitabine } \\
\text { Median PFS: } 9.6 \text { months versus } \\
6.4 \text { months (HR: } 0.65 ; P<0.001) \\
\text { Median OS: } 30.9 \text { months versus } \\
25.1 \text { months (HR: } 0.68 ; P<0.001 \text { ) }\end{array}$ \\
\hline BOLERO- $3^{[30]}$ & $\begin{array}{l}\text { Trastuzumab }+ \text { vinorelbine } \\
+ \text { everolimus }(n=284) \text { versus } \\
\text { trastuzumab }+ \text { vinorelbine }+ \\
\text { placebo }(n=285)\end{array}$ & $\begin{array}{l}\text { LABC or metastatic HER2-positive } \\
\text { breast cancer: Recurrence during or } \\
<12 \text { months of adjuvant treatment or } \\
\text { progression during or }<4 \text { weeks of } \\
\text { treatment for advanced disease }\end{array}$ & $\begin{array}{l}\text { Trastuzumab }+ \text { vinorelbine }+ \\
\text { everolimus versus trastuzumab }+ \\
\text { vinorelbine } \\
\text { Median PFS: } 7 \text { months versus } \\
5.8 \text { months (HR: } 0.78 ; P=0.0067 \text { ) }\end{array}$ \\
\hline LUX breast- $1^{[31]}$ & $\begin{array}{l}\text { Vinorelbine }+ \text { afatinib }(n=339) \\
\text { versus vinorelbine }+ \text { trastuzumab } \\
(n=169)\end{array}$ & $\begin{array}{l}\text { HER2-positive } \mathrm{mBC} \text { who had } \\
\text { progressed on or }<12 \text { months following } \\
\text { adjuvant trastuzumab or first-line } \\
\text { treatment of metastatic disease with } \\
\text { trastuzumab }\end{array}$ & $\begin{array}{l}\text { Vinorelbine }+ \text { afatinib versus } \\
\text { vinorelbine }+ \text { trastuzumab } \\
\text { Median PFS: } 5.5 \text { months versus } \\
5.6 \text { months (HR: } 1.10 ; P=0.043 \text { ) } \\
\text { Median OS: } 20.5 \text { months versus } \\
28.6 \text { months (HR: } 1.48 ; P=0.048 \text { ) }\end{array}$ \\
\hline PHEREXA $^{[32,33]}$ & $\begin{array}{l}\text { Pertuzumab }+ \text { trastuzumab }+ \\
\text { capecitabine }(n=228) \text { versus } \\
\text { trastuzumab }+ \text { capecitabine } \\
(n=224)\end{array}$ & $\begin{array}{l}\text { HER2-positive } \mathrm{mBC} \text { : Experienced } \\
\text { disease progression during or after } \\
\text { trastuzumab-based therapy; received a } \\
\text { prior taxane }\end{array}$ & $\begin{array}{l}\text { Pertuzumab }+ \text { trastuzumab }+ \\
\text { capecitabine versus trastuzumab }+ \\
\text { capecitabine } \\
\text { Median PFS } 11.1 \text { months versus } \\
9 \text { months (HR: } 0.82 ; P=0.0731 \text { ) } \\
\text { Median OS } 36.1 \text { months versus } \\
28.1 \text { months (HR: } 0.68 ; P=N R)\end{array}$ \\
\hline
\end{tabular}

HER2 - Human epidermal growth factor receptor 2; LABC - Locally advanced breast cancer; mBC - Metastatic breast cancer; OS - Overall survival; PFS - Progression-free survival; T-DM1 - Trastuzumab emtansine; TTP - Time to progression; HR - Hazard ratio; $\mathrm{NR}=$ Statistical significance for OS cannot be claimed because of the hierarchical testing of OS after the primary PFS end point

In the LUX Breast-1 study, patients who progressed on trastuzumab fared better on further trastuzumab than on the pan-HER2 inhibitor afatinib [Table 3]. The reason could be related to the differing mechanisms of antibody versus small molecule, as well as to the immunological effects. However, the treatment was associated with an unfavorable benefit/risk ratio. ${ }^{[31]}$

The results of PHEREXA trial presented at the ASCO 2016 showed that addition of pertuzumab to trastuzumab plus capecitabine as the second-line treatment of patients with $\mathrm{mBC}$ did not significantly improve PFS. ${ }^{[32,33]}$

\section{Panel recommendation}

On a review of all trials in the context of patients who progressed on trastuzumab, a survival advantage was evident only in the EMILIA trial in those treated with T-DM1. In the absence of cost constraints, T-DM1 would be the preferred choice in this setting.

The panel also recommends that in patients with HER2-positive $\mathrm{mBC}$ who show indolent progression on a trastuzumab-based regimen, a change of the chemotherapy partner or re-introduction of chemotherapy, with continuation of trastuzumab, could also be a viable option.

\section{Clinical Scenario 3: Central Nervous System Metastases in Human Epidermal Growth Factor Receptor 2-Positive Breast Cancer}

A 52-year-old woman presented with HER2-positive, hormone receptor-positive, invasive ductal carcinoma of the breast (T2N1M0; $32 \mathrm{~mm}$, Grade 3 with 5 of 14 lymph nodes involved). She received adjuvant chemotherapy with docetaxel in combination with carboplatin and trastuzumab (TCH) and continued on trastuzumab monotherapy (to complete 1 year) with aromatase inhibitor. One year later, she developed biopsy-confirmed HER2-positive and hormone receptor-positive metastases in liver. She received six cycles of paclitaxel with trastuzumab. After 6 months on trastuzumab monotherapy, she developed multiple unresectable central nervous system (CNS) metastasis. 
For this scenario, the following treatment regimens were considered for the discussion:

1. Continue trastuzumab with locoregional treatment of CNS metastasis

2. Change to a combination of lapatinib and capecitabine

3. Locoregional treatment of CNS metastasis followed by T-DM1.

\section{Literature analysis}

There is some evidence, although not from randomized trials, that use of chemotherapy and HER2-targeted therapy in addition to brain radiation might improve OS in patients with CNS metastasis. ${ }^{[34]}$
Human epidermal growth factor receptor 2-positive metastatic breast cancer without central nervous system metastasis at baseline

A retrospective study by Park et al. showed that addition of trastuzumab to chemotherapy increased the time to onset of CNS metastasis (15 months vs. 10 months, $P=0.035$ ) and time to death from CNS metastases (14.9 months vs. 4.0 months, $P=0.0005$ ) in patients with HER2-positive mBC. However, among patients with HER2-positive disease, the incidence of CNS metastasis in those treated with trastuzumab (37.8\%) was higher than that in patients who were not treated with trastuzumab $(25.0 \% ; P=0.028) \cdot{ }^{[35]}$ It is worth noting that following

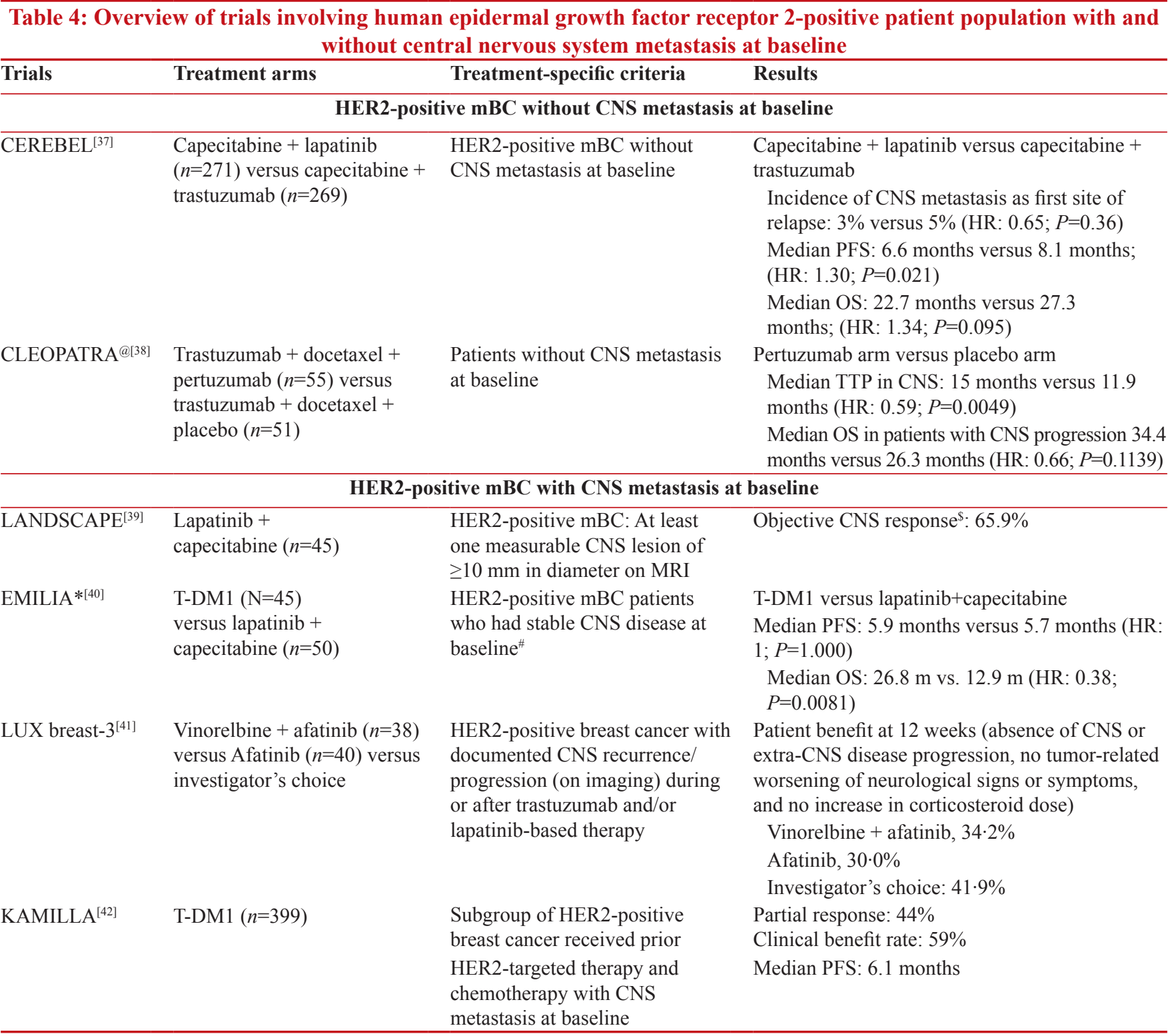

neurological symptoms and progressive extra-CNS disease; "Patients with asymptomatic CNS metastases previously treated with radiotherapy were eligible to enroll 14 days after last radiotherapy treatment. CNS - Central nervous system; HER2 - Human epidermal growth factor receptor 2; LABC - Locally advanced breast cancer; mBC - Metastatic breast cancer; MRI - Magnetic resonance imaging; HR - Hazard ratio; OS - Overall survival; PFS - Progression-free survival; T-DM1 - Trastuzumab emtansine; TTP - Time to progression 
radiation therapy, the concentration of trastuzumab in the cerebrospinal fluid tends to increase. ${ }^{[36]}$

In the CEREBEL trial, no significant difference was observed between the lapatinib plus capecitabine and the trastuzumab plus capecitabine arms with respect to time to metastasis and development of new CNS metastasis [5.7 and 4.4 months, respectively; Table 4]. Further, there was low overall incidence of CNS progression at any time (7\% and $6 \%$, respectively). ${ }^{[37]}$

In the CLEOPATRA study, the combination of pertuzumab, trastuzumab, and docetaxel was superior to that of placebo, trastuzumab, and docetaxel in delaying the onset of CNS disease [Table 4], an effect that is likely attributable to the superior systemic disease control achieved with pertuzumab-based treatment. ${ }^{[38]}$

Human epidermal growth factor receptor 2-positive metastatic breast cancer with central nervous system metastasis at baseline

In a pivotal study that led to the approval of lapatinib in HER2-positive $\mathrm{mBC}$, the incidence of CNS disease in the lapatinib plus capecitabine arm was lower than that in the capecitabine alone arm; however, the difference was not statistically significant. ${ }^{[9]}$ The LANDSCAPE study was an exploratory single-arm, Phase 2, open-label, multicenter study, which evaluated the combination of lapatinib and capecitabine for the treatment of previously untreated CNS metastases from HER2-positive breast cancer. Partial response was evident in all patients, and objective CNS response was observed in nearly $70 \%$ of the patients [Table 4]. ${ }^{[39]}$

In the EMILIA study, some patients (95 out of 991) had CNS metastasis at baseline, a majority of whom had received whole-brain radiotherapy. The patients were asymptomatic at baseline. Post hoc analysis showed significant survival benefits following treatment with T-DM1 as compared to that with lapatinib and capecitabine combination [Table 4]. ${ }^{40]}$

In the LUX Breast 3 study (afatinib alone vs. afatinib plus vinorelbine vs. investigators' choice), there was no significant difference in the PFS and OS or patient benefits between the three treatment arms [Table 3]; however, patients treated with afatinib experienced more frequent adverse events. ${ }^{[41]}$

A more recent presentation on a large cohort of patients $(n=399)$ with CNS metastasis suggested a clinical benefit rate of $43 \%$ with T-DM1 in those with measureable CNS disease. $^{[42]}$

\section{Panel recommendation}

Owing to lack of robust evidence in this specific group of patients, deciding on systemic anti-HER2 therapy is challenging. Based on the indirect evidence generated by the EMILIA study, T-DM1 can be considered as an option in patients with HER2-positive CNS metastasis who have received radiotherapy. The survival benefit in patients with asymptomatic metastasis could be attributed to control extracranial disease rather than to the effect of the drug on CNS metastasis. However, other options including trastuzumab or lapatinib can also be considered based on the characteristics of individual patients. It is important to note that the outcome of patients with HER2-positive CNS metastasis may be better than those with triple-negative breast cancer.

The panel recommends initial locoregional treatment of CNS metastasis, followed by T-DM1 as a preferred option in this scenario, although trastuzumab- or lapatinib-based combination therapy could also be considered.

\section{Clinical Scenario 4: HER2-Positive Metastatic Breast Cancer Progressing on Two Prior Anti-HER2 Agents}

A 60-year-old woman presented to the emergency department with persistent cough and dyspnea on exertion. Five years ago, she was diagnosed with Stage II, HER2-positive and hormone receptor-positive breast cancer. Postsurgery, she received AC-TH followed by tamoxifen for 4 years. Six months ago, the cancer recurred as a solitary pulmonary lesion, and she was treated with trastuzumab and anastrozole. After 2 months, the patient developed increased cough and difficulty in breathing. She was then treated with lapatinib and capecitabine. Currently, she exhibits signs of progression with appearance of liver metastasis and enlargement of the pulmonary lesion.

The following treatment regimens were considered for discussion in this scenario of a HER2-positive mBC patient who progresses on two anti-HER2 agents:

1. Continue trastuzumab but change chemotherapy partner

2. Continue with lapatinib and capecitabine

3. T-DM1

4. Lapatinib and trastuzumab

5. Chemotherapy alone.

\section{Literature analysis}

In the TH3RESA trial, the median number of previous regimens for advanced breast cancer was 4 or 5 . The PFS and OS in patients treated with T-DM1 were significantly better than those associated with treatment of physicians' choice [Table 5], which was mainly trastuzumab-containing combinations ( $80 \%$ patients). ${ }^{[43,44]}$

In the EGF104900 trial, the median number of prior anti-HER2 therapies for $\mathrm{mBC}$ was 3 . PFS and OS in the lapatinib plus trastuzumab arm were significantly longer than that with lapatinib alone [Table 5]. Improvement in absolute OS rate at 6 and 12 months was $10 \%$ and $15 \%$, respectively, in the combination arm compared with the monotherapy arm. ${ }^{[4,46]}$ 


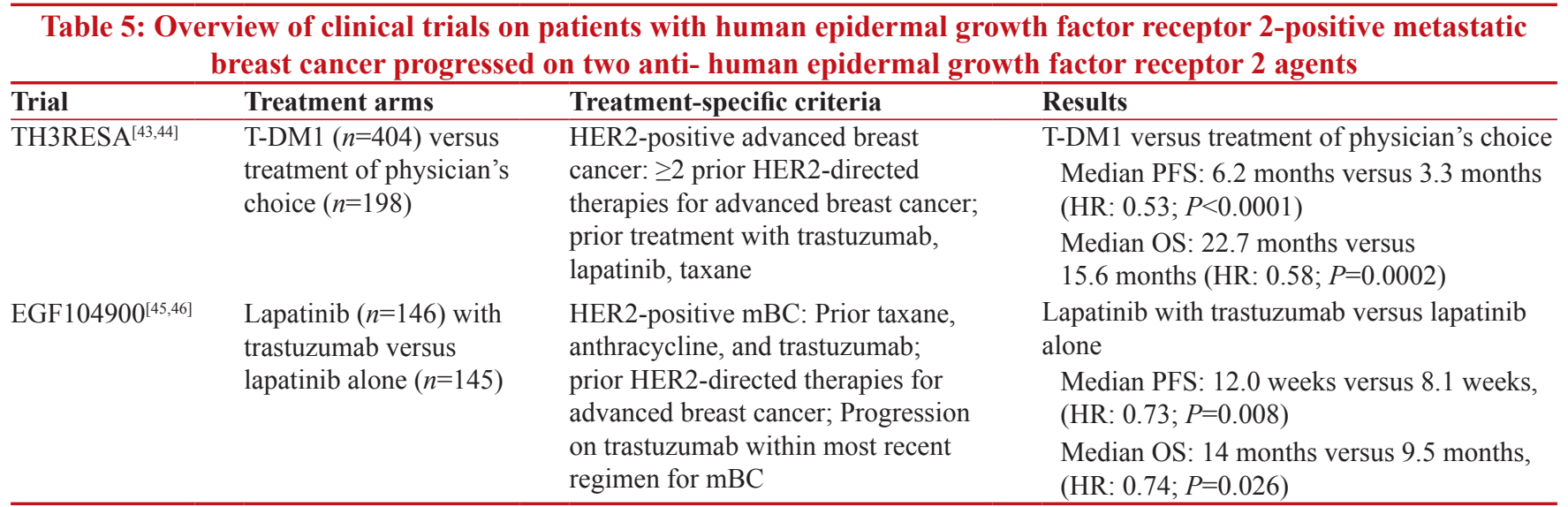

HER2 - Human epidermal growth factor receptor 2; LABC - Locally advanced breast cancer; mBC - Metastatic breast cancer; MRI - Magnetic resonance imaging; HR - Hazard ratio; OS - Overall survival; PFS - Progression-free survival; T-DM1 - Trastuzumab emtansine

\section{Panel recommendations}

For patients with HER2-positive $\mathrm{mBC}$ who progress on anti-HER2 agents (trastuzumab and lapatinib), T-DM1 should be the treatment of choice. An alternative option may be chemotherapy in combination with trastuzumab. For heavily pretreated patients who have received multiple lines of treatment, a dual HER2-targeted regimen (i.e., trastuzumab and lapatinib) may be considered.

\section{Conclusion}

Based on evidence from multiple well-conducted clinical trials, anti-HER2 therapy has become a central element in the therapeutic strategy for HER2-positive mBC leading to a paradigm shift in the management of HER2-positive breast cancer. In the Indian scenario, in addition to available evidence, socioeconomic variables would need to be considered by treating physicians. The panel of experts has summarized the evidence and made recommendations pertaining to commonly encountered clinical scenarios in HER2-positive $\mathrm{mBC}$ that may potentially improve patient outcomes.

\section{Acknowledgment}

The authors would like to acknowledge medical writing and editing support provided by A Dharman, S Verma, and KS Saini of Quantum Health Analytics SPRL, Belgium.

\section{Financial support and sponsorship}

Roche Products (India) Pvt. Ltd. provided financial support for this scientific/educational project at no detriment to the freedom to prescribe and to choose treatment. Roche does not recommend or endorse any use, preparation. or administration of the products, which is outside of their prescribing information.

\section{Conflicts of interest}

The authors have no conflicts of interest to declare except for Dr. Jagdish Nigade, Dr. Anil Kukreja, Dr. Binay Swarup, and Priyanka Bhattacharya who are full-time employees of Roche Products (India) Pvt. Ltd.

\section{References}

1. Owens MA, Horten BC, Da Silva MM. HER2 amplification ratios by fluorescence in situ hybridization and correlation with immunohistochemistry in a cohort of 6556 breast cancer tissues. Clin Breast Cancer 2004;5:63-9.

2. Saini KS, Azim HA Jr., Metzger-Filho O, Loi S, Sotiriou C, de Azambuja E, et al. Beyond trastuzumab: New treatment options for HER2-positive breast cancer. Breast 2011;20 Suppl 3:S20-7.

3. Ghosh J, Gupta S, Desai S, Shet T, Radhakrishnan S, Suryavanshi $\mathrm{P}$, et al. Estrogen, progesterone and HER2 receptor expression in breast tumors of patients, and their usage of HER2-targeted therapy, in a tertiary care centre in India. Indian J Cancer 2011;48:391-6.

4. Doval DC, Sharma A, Sinha R, Kumar K, Dewan AK, Chaturvedi $\mathrm{H}$, et al. Immunohistochemical profile of breast cancer patients at a tertiary care hospital in New Delhi, India. Asian Pac J Cancer Prev 2015;16:4959-64.

5. Chatterjee S, Saha A, Arun I, Nayak SS, Sinha S, Agrawal S, et al. Correlation of clinicopathological outcomes with changes in IHC4 status after NACT in locally advanced breast cancers: Do pre-NACT ER/PR status act as better prognosticators? Breast Cancer (Dove Med Press) 2015;7:381-8.

6. Agrawal S, Banswal L, Saha A, Arun I, Datta SS, Chatterjee S, et al. Progesterone receptors, pathological complete response and early outcome for locally advanced breast cancer - A single centre study. (PPLB - 01). Indian J Surg Oncol 2016;7:397-406.

7. Slamon DJ, Clark GM, Wong SG, Levin WJ, Ullrich A, McGuire WL, et al. Human breast cancer: Correlation of relapse and survival with amplification of the HER-2/neu oncogene. Science 1987;235:177-82.

8. Slamon DJ, Leyland-Jones B, Shak S, Fuchs H, Paton V, Bajamonde A, et al. Use of chemotherapy plus a monoclonal antibody against HER2 for metastatic breast cancer that overexpresses HER2. N Engl J Med 2001;344:783-92.

9. Geyer CE, Forster J, Lindquist D, Chan S, Romieu CG, Pienkowski $\mathrm{T}$, et al. Lapatinib plus capecitabine for HER2-positive advanced breast cancer. $N$ Engl J Med 2006;355:2733-43.

10. Baselga J, Cortés J, Kim SB, Im SA, Hegg R, Im YH, et al. 
Pertuzumab plus trastuzumab plus docetaxel for metastatic breast cancer. N Engl J Med 2012;366:109-19.

11. Verma S, Miles D, Gianni L, Krop IE, Welslau M, Baselga J, et al. Trastuzumab emtansine for HER2-positive advanced breast cancer. N Engl J Med 2012;367:1783-91.

12. Genentech (A Member of the Roche group); Herceptin ${ }^{\circledR}$ (Trastuzumab) Development Timeline. Available from: https://www.gene.com/media/product-information/herceptindevelopment-timeline. [Last accessed on 2017 Jun 19].

13. Gelmon KA, Boyle FM, Kaufman B, Huntsman DG, Manikhas A, Di Leo A, et al. Lapatinib or trastuzumab plus taxane therapy for human epidermal growth factor receptor 2-positive advanced breast cancer: Final results of NCIC CTG MA.31. J Clin Oncol 2015;33:1574-83.

14. Swain SM, Baselga J, Kim SB, Ro J, Semiglazov V, Campone M, et al. Pertuzumab, trastuzumab, and docetaxel in HER2-positive metastatic breast cancer. N Engl J Med 2015;372:724-34.

15. Ciruelos Gil EM, Brufsky A, Im YH, Kim SB, Clark E, Knott A, et al. Efficacy and safety of first-line (1L) pertuzumab (P), trastuzumab (T), and docetaxel (D) in HER2-positive MBC (CLEOPATRA) in patients previously exposed to trastuzumab. J Clin Oncol 2013;31 15 Suppl:600.

16. Hurvitz SA, Andre F, Jiang Z, Shao Z, Mano MS, Neciosup SP, et al. Combination of everolimus with trastuzumab plus paclitaxel as first-line treatment for patients with HER2-positive advanced breast cancer (BOLERO-1): A phase 3, randomised, double-blind, multicentre trial. Lancet Oncol 2015;16:816-29.

17. Perez EA, Barrios C, Eiermann W, Toi M, Im YH, Conte P, et al. Trastuzumab emtansine with or without pertuzumab versus trastuzumab plus taxane for human epidermal growth factor receptor 2-positive, advanced breast cancer: Primary results from the phase III MARIANNE study. J Clin Oncol 2017;35:141-8.

18. Kadycla. Summary of Product Characteristics. Available from: https://www.ec.europa.eu/health/documents/communityregister/2013/20131115127009/anx_127009_en.pdf. [Last accessed on 2017 Jun 19].

19. Swain SM, Clark E, Baselga J. Treatment of HER2-positive metastatic breast cancer. N Engl J Med 2015;372:1964-5.

20. Davies C, Pan H, Godwin J, Gray R, Arriagada R, Raina V, et al. Long-term effects of continuing adjuvant tamoxifen to 10 years versus stopping at 5 years after diagnosis of oestrogen receptor-positive breast cancer: ATLAS, a randomised trial. Lancet 2013;381:805-16.

21. Baselga J, Cortes J, Im SA, Pivot XB, Clark E, Knott A, et al. Adverse events with pertuzumab and trastuzumab: Evolution during treatment with and without docetaxel in CLEOPATRA. J Clin Oncol 2012;30:597.

22. Miles D, Puglisi F, Schneeweiss A, Ciruelos E, Peretz-Yablonski T, Moreno K, et al. 1816 preliminary safety results from PERUSE, a study of 1436 patients (pts) treated with first-line pertuzumab $(\mathrm{P})$ combined with trastuzumab $(\mathrm{H})$ and taxane therapy for HER2-positive locally recurrent/metastatic breast cancer (LR/mBC). Eur J Cancer 2015;51:S271.

23. Robert NJ, Goertz HP, Chopra P, Jiao X, Yoo B, Patt D, et al. HER2-positive metastatic breast cancer patients receiving pertuzumab in a community oncology practice setting: Treatment patterns and outcomes. Drugs Real World Outcomes 2017;4:1-7.

24. Saini KS, Loi S, de Azambuja E, Metzger-Filho O, Saini ML, Ignatiadis $\mathrm{M}$, et al. Targeting the $\mathrm{PI} 3 \mathrm{~K} / \mathrm{AKT} / \mathrm{mTOR}$ and raf/MEK/ERK pathways in the treatment of breast cancer. Cancer Treat Rev 2013;39:935-46.

25. Yardley DA, Kaufman PA, Brufsky A, Yood MU, Rugo H, Mayer $\mathrm{M}$, et al. Treatment patterns and clinical outcomes for patients with de novo versus recurrent HER2-positive metastatic breast cancer. Breast Cancer Res Treat 2014;145:725-34.

26. Wong NS, Anderson BO, Khoo KS, Ang PT, Yip CH, Lu YS, et al. Management of HER2-positive breast cancer in Asia: Consensus statement from the Asian Oncology Summit 2009. Lancet Oncol 2009;10:1077-85.

27. Durkee BY, Qian Y, Pollom EL, King MT, Dudley SA, Shaffer JL, et al. Cost-effectiveness of pertuzumab in human epidermal growth factor receptor 2-positive metastatic breast cancer. J Clin Oncol 2016;34:902-9.

28. Cameron D, Casey M, Press M, Lindquist D, Pienkowski T, Romieu CG, et al. A phase III randomized comparison of lapatinib plus capecitabine versus capecitabine alone in women with advanced breast cancer that has progressed on trastuzumab: Updated efficacy and biomarker analyses. Breast Cancer Res Treat 2008;112:533-43.

29. Cameron D, Casey M, Oliva C, Newstat B, Imwalle B, Geyer CE, et al. Lapatinib plus capecitabine in women with HER-2-positive advanced breast cancer: Final survival analysis of a phase III randomized trial. Oncologist 2010;15:924-34.

30. André F, O’Regan R, Ozguroglu M, Toi M, Xu B, Jerusalem G, et al. Everolimus for women with trastuzumab-resistant, HER2-positive, advanced breast cancer (BOLERO-3): A randomised, double-blind, placebo-controlled phase 3 trial. Lancet Oncol 2014;15:580-91.

31. Harbeck N, Huang CS, Hurvitz S, Yeh DC, Shao Z, Im SA, et al. Afatinib plus vinorelbine versus trastuzumab plus vinorelbine in patients with HER2-overexpressing metastatic breast cancer who had progressed on one previous trastuzumab treatment (LUX-breast 1): An open-label, randomised, phase 3 trial. Lancet Oncol 2016;17:357-66.

32. Urruticoechea A, Rizwanullah M, Im S, Sánchez-Ruiz AC, Lang I, Tomasello G, et al. PHEREXA: A phase III study of trastuzumab + capecitabine $+/$ - pertuzumab for patients who progressed during/after one line of trastuzumab-based therapy in the HER2-positive metastatic breast cancer setting. J Clin Oncol 34, no. 15_suppl (May 20 2016): Abstract 504.

33. Urruticoechea A, Rizwanullah M, Im SA, Ruiz ACS, Láng I, Tomasello G, et al. Randomized phase III trial of trastuzumab plus capecitabine with or without pertuzumab in patients with human epidermal growth factor receptor 2-positive metastatic breast cancer who experienced disease progression during or after trastuzumab-based therapy. J Clin Oncol 2017;35:3030-8.

34. Kim HJ, Im SA, Keam B, Kim YJ, Han SW, Kim TM, et al. Clinical outcome of central nervous system metastases from breast cancer: Differences in survival depending on systemic treatment. J Neurooncol 2012;106:303-13.

35. Park YH, Park MJ, Ji SH, Yi SY, Lim DH, Nam DH, et al. Trastuzumab treatment improves brain metastasis outcomes through control and durable prolongation of systemic extracranial disease in HER2-overexpressing breast cancer patients. $\mathrm{Br} \mathrm{J}$ Cancer 2009;100:894-900.

36. Stemmler HJ, Schmitt M, Willems A, Bernhard H, Harbeck N, Heinemann V, et al. Ratio of trastuzumab levels in serum and cerebrospinal fluid is altered in HER2-positive breast cancer patients with brain metastases and impairment of blood-brain barrier. Anticancer Drugs 2007;18:23-8.

37. Pivot $\mathrm{X}$, Manikhas A, Żurawski B, Chmielowska E, Karaszewska B, Allerton R, et al. CEREBEL (EGF111438): A Phase III, randomized, open-label study of lapatinib plus capecitabine versus trastuzumab plus capecitabine in patients with human epidermal growth factor receptor 2-positive metastatic breast cancer. J Clin Oncol 2015;33:1564-73.

38. Swain SM, Baselga J, Miles D, Im YH, Quah C, Lee LF, et al. Incidence of central nervous system metastases in patients with 
HER2-positive metastatic breast cancer treated with pertuzumab, trastuzumab, and docetaxel: Results from the randomized phase III study CLEOPATRA. Ann Oncol 2014;25:1116-21.

39. Bachelot T, Romieu G, Campone M, Diéras V, Cropet C, Dalenc F, et al. Lapatinib plus capecitabine in patients with previously untreated brain metastases from HER2-positive metastatic breast cancer (LANDSCAPE): A single-group phase 2 study. Lancet Oncol 2013;14:64-71.

40. Krop IE, Lin NU, Blackwell K, Guardino E, Huober J, Lu M, et al. Trastuzumab emtansine (T-DM1) versus lapatinib plus capecitabine in patients with HER2-positive metastatic breast cancer and central nervous system metastases: A retrospective, exploratory analysis in EMILIA. Ann Oncol 2015;26:113-9.

41. Cortés J, Dieras V, Ro J, Barriere J, Bachelot T, Hurvitz S, et al. Afatinib alone or afatinib plus vinorelbine versus investigator's choice of treatment for HER2-positive breast cancer with progressive brain metastases after trastuzumab, lapatinib, or both (LUX-breast 3): A randomised, open-label, multicentre, phase 2 trial. Lancet Oncol 2015;16:1700-10.

42. Montemurro F, Ellis P, Delaloge S, Wuerstlein R, Anton A, Button $\mathrm{P}$, et al. Safety and efficacy of trastuzumab emtansine (T-DM1) in 399 patients with central nervous system metastases: Exploratory subgroup analysis from the KAMILLA study. Cancer Res 2017;77 4 Suppl:P1-12-10.

43. Krop IE, Kim SB, González-Martín A, LoRusso PM, Ferrero JM, Smitt M, et al. Trastuzumab emtansine versus treatment of physician's choice for pretreated HER2-positive advanced breast cancer (TH3RESA): A randomised, open-label, phase 3 trial. Lancet Oncol 2014;15:689-99.

44. Wildiers H, Kim SB, Gonzalez-Martin A,LoRusso PM, Ferrero JM, Yu R, et al. Trastuzumab emtansine improves overall survival versus treatment of physician's choice in patients with previously treated HER2-positive metastatic breast cancer: Final overall survival results from the phase 3 TH3RESA study. Cancer Res 2016;76 (4 Suppl): S5-05.

45. Blackwell KL, Burstein HJ, Storniolo AM, Rugo H, Sledge G, Koehler M, et al. Randomized study of lapatinib alone or in combination with trastuzumab in women with erbB2-positive, trastuzumab-refractory metastatic breast cancer. J Clin Oncol 2010;28:1124-30.

46. Blackwell KL, Burstein HJ, Storniolo AM, Rugo HS, Sledge G, Aktan G, et al. Overall survival benefit with lapatinib in combination with trastuzumab for patients with human epidermal growth factor receptor 2-positive metastatic breast cancer: Final results from the EGF104900 study. J Clin Oncol 2012;30:2585-92. 